\title{
THE PHYSIOLOGICAL AND NUTRITIONAL CONTENT CHANGES OF JELUTUNG (Dyera polyphylla (Miq.) Steenis) SEED THROUGH DRYING
} AND STORAGE

\author{
Naning Yuniarti* and Nurhasybi \\ Forest Tree Seed Technology Research and Development Institute \\ Jl. Pakuan Ciheuleut, Bogor, Indonesia
}

Received: 21 January 2016, Revised: 29 April 2018, Accepted: 30 April 2018

THE PHYSIOLOGICAL AND NUTRITIONAL CONTENT CHANGES OF JELUTUNG (Dyera polyphylla (Miq.) Steenis) SEED THROUGH DRYING AND STORAGE. Seed deterioration is the process of deteriorated seed in view of viability that has changed its physiological and nutritional content. This paper studies the effect of seed drying and seed storage to the viability and biochemical content of jelutung (Dyera polyphylla (Miq.) Steenis) seeds. Completely Randomized Design was used for different level of seed drying time, i.e. 0, 24, 48, 72, 96 and 120 hours, and Completely Randomized Factorial Design was used for the combination of seed drying treatments of $0,24,48,72,96$ and 120 hours in different rooms for seed storage (ambient room, air conditioned room, refrigerator) with variables of moisture content, germination percentage and nutritional content. Result shows that seed drying and seed storage treatments pursue the change of seed viability and nutritional content of jelutung seed. The period of time in seed drying and seed storage siginificantly influence the moisture content, germination percentage and nutritional composition (lipid, carbohydrate, protein). The longer time of seed drying will effect significantly to the moisture content and germination percentage, increasing the lipid and protein and decreasing carbohydrate. Jelutung seed that was stored in air conditioned room had better viability compared to ambient room and refrigerator.

Keywords: Jelutung seed, viability, nutritional, seed drying, seed storage

PERUBAHAN FISIOLOGI DAN KANDUNGAN NUTRISI BENIH JELUTUNG (Dyera polyphylla (Miq.) Steenis) PADA PROSES PENGERINGAN DAN PENYIMPANAN. Secara alami benih jelutung seiring dengan bertambahnya waktu akan mengalami kemunduran mutu benih yang dapat menyebabkan perubahan baik. fisik, fisiologis maupun nutrisi yang mengakibatkan menurunnya viabilitas benib. Tujuan penelitian ini adalah untuk menguji pengaruh lama pengeringan dan ruang penyimpanan terhadap viabilitas dan komposisi nutrisi benih jelutung (Dyera polyphylla (Miq.) Steenis). Penelitian pengeringan dirancang dengan menggunakan Rancangan Acak Lengkap dengan waktu pengeringan selama 0, 24, 48, 72, 96, dan 120 jam, sedangkan pengujian viabilitas dan kandungan nutrisi benib terhadap lama pengeringan dan ruang penyimpanan menggunakan $\mathrm{R} A L$ pola faktorial dengan dua faktor, yaitu faktor lama pengeringan benib (0, 24, 48, 72, 96, dan 120 jam) dan faktor ruang simpan (ruang subu kamar, AC, kulkas). Kedua tahapan penelitian menggunakan peubah kadar air benih, daya berkecambah dan kandungan nutrisi benih. Hasil yang diperoleh yaitu lama pengeringan dan ruang penyimpanan mengakibatkan perubahan viabilitas dan kandungan biokimia pada benih jelutung. Interaksi lama pengeringan dan ruang penyimpanan berpengaruh nyata terhadap nilai kadar air, daya berkecambah, dan kandungan nutrisi (lemak, karbobidrat, protein) benih jelutung. Semakin lama pengeringan, akan menyebabkan menurunny nilai kadar air dan daya berkecambah, meningkatnya kadar lemak dan protein, serta menurunnya kadar karbohidrat pada benih jelutung. Benih jelutung yang disimpan di ruang $A C$ dapat menghasilkan viabilitas benih yang lebih baik dibandingkan dengan penyimpanan di ruang kamar dan kulkas.

Kata kunci: Benih jelutung, viabilitas, nutrisi, pengeringan, penyimpanan

*Corresponding author: naningbtp@yahoo.co.id 


\section{INTRODUCTION}

Jelutung (Dyera polyphylla (Miq.) Steenis) belongs to the family of Apocynaceae, which includes 366 generas that were recognized and placed in five subfamilies, 25 tribes and 49 subtribes based on the recent morphological and molecular, mainly in phylogenetic-based results (Endress, Shumann \& Meve, 2014). Jelutung naturally growth in swamp-land area through seed dispersal from the mother trees in some locations in Kalimantan and Sumatera including West Kalimantan, Central Kalimantan, West Sumatera, South Sumatera, Bengkulu, Jambi and Aceh (Perdana, Sofyuddin, Harun \& Widayati, 2016; Tata, Noordwijk, Jasnari \& Widayati, 2015a). The biological cycle of this species is more than 30 years and the economic cycle between 6 to 30 years for tapping jelutung latex and harvesting its wood after 30 years (Bastoni, 2014). Jelutung latex could be used as raw material for producing edible gum, a mixture of automobile tyre manufacture, making paints, adhesives and varnishes (Waluyo, Wahyudi \& Santosa, 2012). Jelutung wood is suitable for pencils, interior design material and wood carving (Perdana, Sofyuddin, Harun \& Widayati, 2016).

Considering its growth potential and the use of its wood, jelutung is a promising species for timber plantation. High seed quality is required in large numbers for the planting programme and seed improvements can be achieved through the right time for seed collection, a good seed handling and secure storage. The plant propagation of jelutung has been using seed and there is no information yet about using vegetative method (Danu \& Wijaya, 2012; Tata, Bastoni, Sofiyuddin, Mulyautami, Perdana \& Janudianto, 2015b). Jelutung can be planted in various mixed agroforestry systems, with other plants including rubber, coffee or oil palms (Tata, Noordwijk, Jasnari \& Widayati, 2015a) and this species has been promoted in peatland rehabilitation and restoration programs (Gunawan et al., 2016; Perdana, Sofyuddin, Harun \& Widayati, 2016).
The jelutung trees has fruiting season every year with good year every two years in Sumatera. However, the flowering usually takes time in November and the mature fruit will be found some times between April and May. However, after 2005 the flowering and fruiting season is unpredictable (Bastoni, 2014). The flowering season for jelutung trees in Central Kalimantan is grouped into two seasons from March to April and from July to December. The development of flower to a mature jelutung fruit may need 5.5 months (Pramono, 2011). Jelutung seed is categorized as intermediate in terms of the initial moisture content of the fresh seed, close to $14 \%$, and it can be stored for up to six months (Kartiko \& Danu, 2016).

One of the problems encountered in providing high quality seed is the maintaining of the seed viability during storage, which can be done by lowering the rate of respiration. High respiration rate leads to rapid loss of seed reserves of energy and food supplies, especially in the embryo. It reduces germination rate and may induce deterioration process of the seed (Widajati, Murniati, Palupi, Kartika, Suhartanto \& Qadir, 2012). Naturally, viability of jelutung seed declines over time. In general, the seeds will face deterioration symptoms (Yuniarti, Syamsuwida \& Aminah, 2008b). Thus a safe seed storage is intended to maintain seed viability which should remain high until the seeds are used for planting.

Some of the factors that affect the viability of the seed during storage are the temperature, moisture content of seeds, relative humidity and oxygen. Their fluctuation during storage can cause changes in respiration rate. Respiration rate continues to increase when the ambient temperature rises that will affect the inactivation of enzymes, nutrients or oxygen reserves can be finished and carbon dioxide will be accumulated. During storage, the seeds that contain more fat are more perishable than those containing more starch or protein (Sudjindro, 1994). By knowing the biochemical content, the proper seed storage techniques and the proper 
testing can be prescribed for the seed. This paper studies the effect of seed drying time and room seed storage on moisture content, viability and biochemical content of jelutung seeds (Dyera polyphylla (Miq.) Steenis).

\section{MATERIAL AND METHOD}

\section{A. Place and Time}

Seed quality testing was conducted in the laboratory and greenhouse of Research and Development Institute for Forest Tree Seed Technology (06³8'07.6”' S and 10602'49'32.2 E), Bogor. The nutritional analysis (e.g. carbohydrate, protein, and fat) were performed in the laboratory of Southeast Asian Regional Centre for Tropical Biology (SEAMEO)Biotrop (06 35'54.7' S - and 106 48'41.3' E) in Bogor. The research was conducted over four months from April to August 2014.

\section{B. Materials and Equipment}

The materials and tools used in the study were the jelutung seed, top soil and sand that have been sterilized as germination medium, aluminium foil, silica gel, sprayer, distilled water, space with room temperature and air conditioning, refrigerator, alcohol, and stationery. The germination medium was sterilized by frying it for two hours on a hot plate.

\section{Method}

Location of seed collection of jelutung was in the Research Forest Area of Tumbang Nusa, Central Kalimantan. Administratively, the location is in Tumbang Nusa Village, Sub district Jabiren Raya, Pulang Pisau Regency, Central Kalimantan Province (02 $18^{\prime} 37^{\prime \prime}$ $02^{\circ} 22^{\prime} 34^{\prime \prime}$ S and $114^{\circ} 02^{\prime} 48^{\prime \prime}$ - $\left.114^{\circ} 06^{\prime} 46^{\prime \prime} \mathrm{E}\right)$. the forest research area is managed by the Banjarbaru Environment and Forestry Research Development Institute.

Seed collection of jelutung was conducted by climbing the trees. The fruit is physiologically ripe when its colour is brown. The seed collection had been conducted in October, 2014 for 4 days. The seed was then sent to
Bogor in one day. The seed extraction was done by drying the fruit in the sun for 7 days. Once dry, the seed was removed from the pod and the seed wing was then cleaned.

\section{Testing I: Effect of seed drying time on seed viability and biochemical content}

Seed drying time treatments used in this research were $0,24,48,72,96$ and 120 hours of four replicates of each treatment in which the seeds were placed on top of nyiru (tray made of rattan) covered by rice paper in ambient room with temperature that varied from $27^{\circ} \mathrm{C}$ to $30^{\circ} \mathrm{C}$.

Determination of seed moisture content, seed germination testing, and analysis of nutritional content (protein, fat, carbohydrates) were conducted at every stage of seed drying time. The number of seed in each treatment required seeds of four replicates@5 g for determination of moisture content, four replicates@100 g for analysis of nutritional content (protein, fat, and carbohydrate), and four replicates@100 seeds for seed germination testing. The determination of seed moisture content was conducted by using the oven method at the constant temperature of $103 \pm 2^{\circ} \mathrm{C}$ for 18 hours.

Seed germination testing of jelutung used sand and soil mixture media $(1: 1 \mathrm{v} / \mathrm{v})$ in the greenhouse. The analysis of nutritional content was conducted in the laboratory of SEAMEOBiotrop in Bogor. Variables observed in this research were seed moisture content, nutritional content (carbohydrate, protein and fat) and germination percentage.

\section{Testing II: Effect of seed drying time and storage type on seed viability and biochemical content}

Two factors were used, namely seed drying time $(0,24,48,72,96,120$ hours $)$ in which the seeds were placed on top of nyiru (tray made of rattan) covered by rice paper in ambient room with temperature that varied from $27^{\circ} \mathrm{C}$ to $30^{\circ} \mathrm{C}$ and storage rooms (ambient room, air conditioned room and refrigerator). Each treatment had four replicates, and each replicate 
required the following number of seeds: $5 \mathrm{~g}$ seeds for testing moisture content, $100 \mathrm{~g}$ seeds for nutritional content analysis (carbohydrate, protein, and fat), and 100 seeds for seed germination testing. Each seed was inserted into bag calico cloth. Seeds in the bag cloth were put in a rectangular box that was given silica gel of the same weight as the seeds, and the seeds were placed in the middle. At bottom layer, silica gel was placed and dried for 0,24 , $48,72,96$ and 120 hours in temperature range from $27^{\circ} \mathrm{C}$ to $30^{\circ} \mathrm{C}$.

The seeds were stored in each storage room, i.e. ambient room (temperature 28$31^{\circ} \mathrm{C}$, RH $70-80 \%$ ), air conditioned room (temperature $18-20^{\circ} \mathrm{C}, \quad \mathrm{RH} \quad 50-60 \%$ ) and refrigerator (temperature $0-5^{\circ} \mathrm{C}, \mathrm{RH} 40-50 \%$ ), using a closed aluminium foil container for two weeks. The seeds were then tested for moisture content by using the oven method at $103 \pm$ $2^{\circ} \mathrm{C}$ for 18 hours, germination testing with media (sand and soil mixture (1: $1 \mathrm{v} / \mathrm{v})$ ), and analysis of nutritional content (carbohydrate, protein, fat). The experimental design used was Factorial Randomized Complete Random (RAL) with two factors, i.e. seed drying time $(0,24,48,72,96,120$ hours $)$ and storage room (ambient room, air conditioned room, refrigerator). The variables to be observed were seed moisture content, germination percentage, and nutritional content (carbohydrate, protein, fat).

\section{Data Analysis}

Data were analyzed by analysis of variance using a completely randomized design (CRD). The LSD test was conducted to reveal significant factor of treatments in statistics that influenced the moisture content, germination percentage and nutritional content of jelutung seed.

\section{RESULT AND DISCUSSION}

\section{A. Testing I: Effect of Seed drying Time on Seed Viability and Nutritional Content}

The analysis of variance showed that the drying time significantly affected the moisture content ( $F$ calculation 293.24), germination percentage ( $\mathrm{F}$ calculation 52.13), fat content (F calculation 38.5), carbohydrate content (F calculation 12.82), and protein content ( $\mathrm{F}$ calculation 27.32) (Figure 1 and 2).

Seed viability, moisture content and nutritional content of jelutung seeds changed because of seed drying. Figure 1 shows the longer the

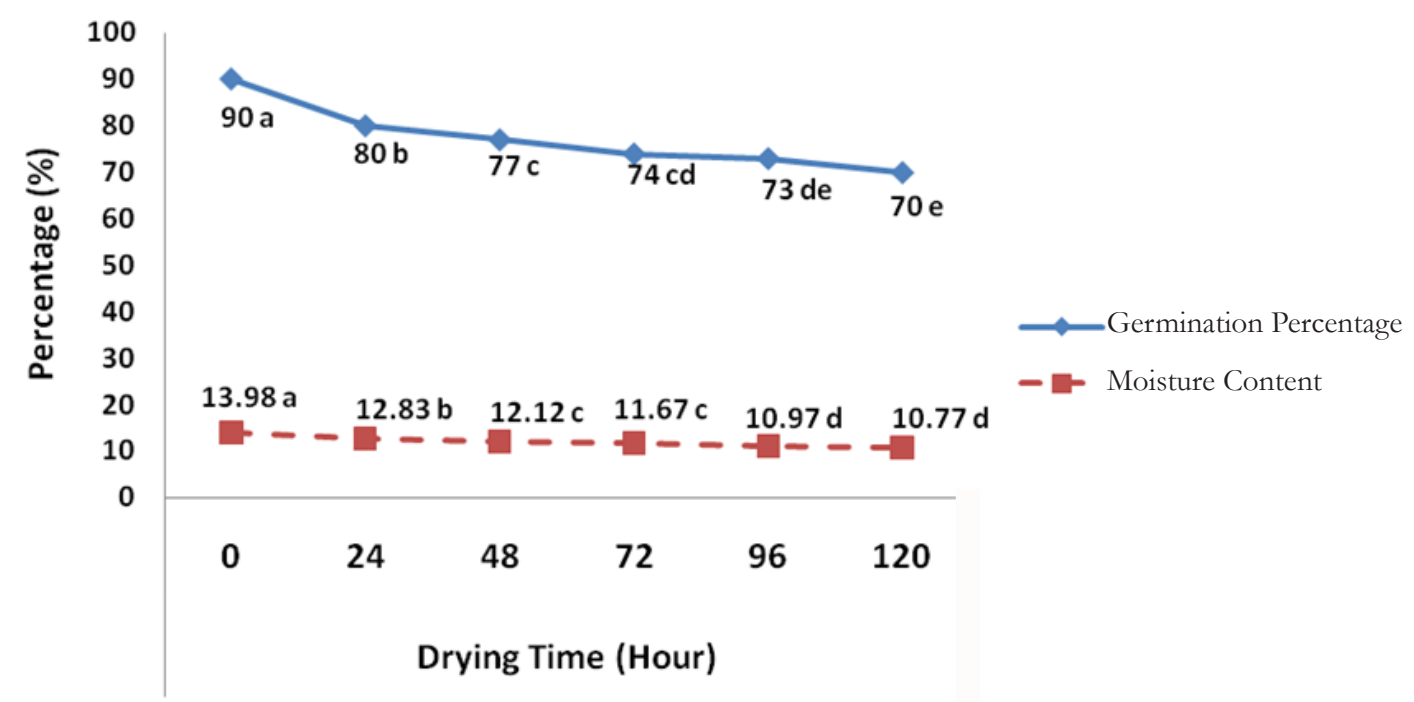

Notes: Values followed by the same letter are not significantly different at 95\% confidence level based on Least Significant Difference Test

Figure 1. Moisture content and germination percentage of jelutung seeds based on drying time 


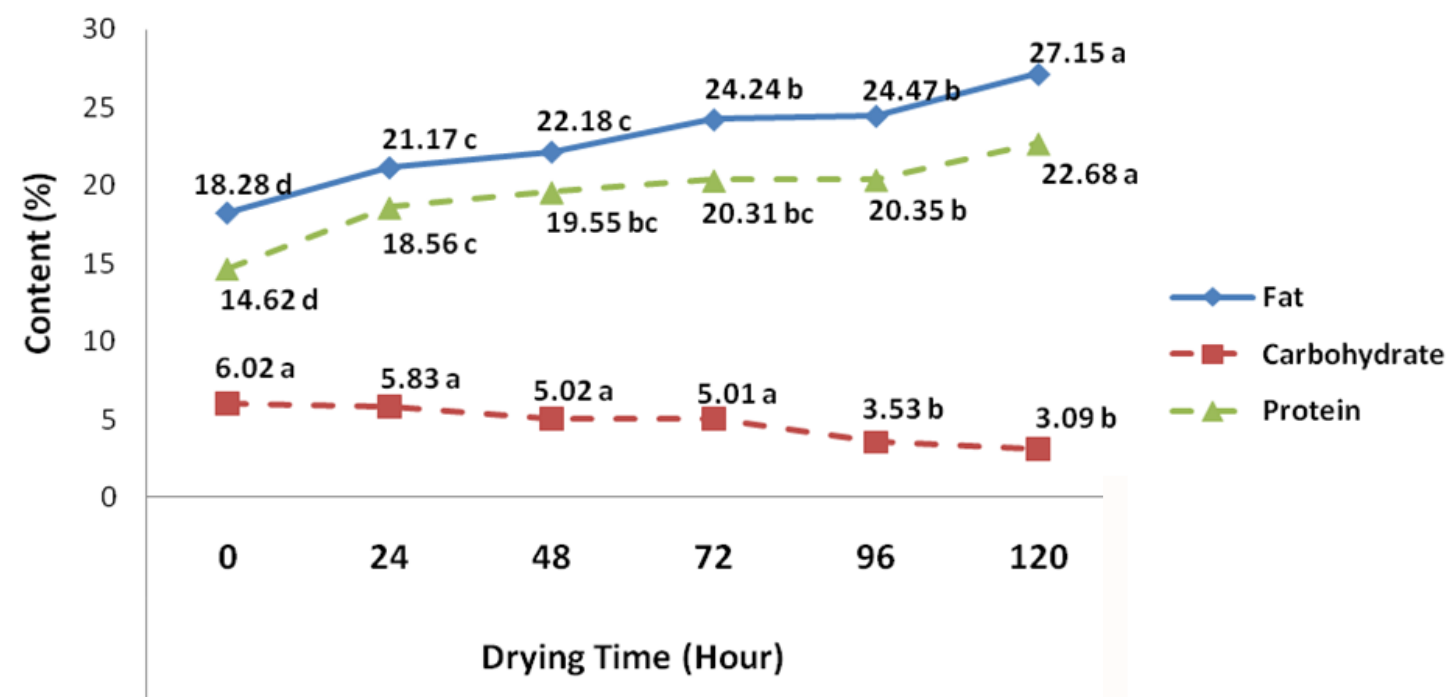

Remarks: Values followed by the same letter are not significantly different at $95 \%$ confidence level based on Least Significance Difference Test

Figure 2. Fat, carbohydrate and protein content of jelutung seed based on drying time

drying time the lower the moisture content and germination percentage of jelutung seeds. The initial moisture content and germination percentage of jelutung seed under control treatment were $13.98 \%$ and $83 \%$, respectively. The germination percentage decreased along with decreasing of moisture content.

The longer drying time led to a slight increase in fat and protein contents, and a slight decrease in carbohydrate content. In the process of drying (moisture reduction) the fat content of the seeds tended to increase contrasting with decreasing water content and germination. (Yuniarti, Syamsuwida \& Aminah, 2008a). The lower moisture content increased the fat content in terms of seed weight, but it decreased seed germination when the seed needed water uptake that was identical to oxygen uptake to germinate (Bonner, Karrfalt \& Nisley, 2008).

In Figure 1, it is known that the nutritional content of the initial (control) jelutung seed has a higher fat content compared to carbohydrate and protein content. During seed drying, jelutung seed increased the levels of fat and protein, and

Table 1. Moisture content of jelutung seed based on interaction of drying time and storage room

\begin{tabular}{|c|c|c|c|c|c|c|c|c|c|c|c|c|}
\hline \multirow{3}{*}{$\begin{array}{l}\text { Drying } \\
\text { Time } \\
\text { (Hour) } \\
\end{array}$} & \multicolumn{12}{|c|}{ Room Storage } \\
\hline & \multicolumn{4}{|c|}{$\mathrm{AC}$} & \multicolumn{4}{|c|}{ Ambient Room } & \multicolumn{4}{|c|}{ Refrigerator } \\
\hline & \multicolumn{2}{|c|}{ Average } & \multirow{2}{*}{$\begin{array}{l} \pm \\
\pm\end{array}$} & \multirow{2}{*}{$\begin{array}{c}\begin{array}{l}\text { Standard } \\
\text { Deviation }\end{array} \\
0.255\end{array}$} & \multicolumn{2}{|c|}{ Average } & \multirow{2}{*}{$\begin{array}{l} \pm \\
\pm\end{array}$} & \multirow{2}{*}{$\begin{array}{c}\text { Standard } \\
\text { Deviation } \\
0.028\end{array}$} & \multicolumn{2}{|c|}{ Average } & \multirow{2}{*}{$\begin{array}{l} \pm \\
\pm\end{array}$} & \multirow{2}{*}{$\begin{array}{c}\begin{array}{c}\text { Standard } \\
\text { Deviation }\end{array} \\
0.219\end{array}$} \\
\hline 0 & 9.220 & $a b$ & & & 9,440 & a & & & 7.325 & e & & \\
\hline 24 & 8.990 & $\mathrm{~b}$ & \pm & 0.127 & 9,100 & $\mathrm{ab}$ & \pm & 0.170 & 6.360 & $f$ & \pm & 0.127 \\
\hline 48 & 8.995 & $\mathrm{~b}$ & \pm & 0.092 & 9,000 & $\mathrm{~b}$ & \pm & 0.113 & 5.615 & g & \pm & 0.219 \\
\hline 72 & 8.890 & $\mathrm{bc}$ & \pm & 0.099 & 8,915 & $\mathrm{bc}$ & \pm & 0.007 & 5.700 & g & \pm & 0.028 \\
\hline 96 & 8.180 & $\mathrm{~d}$ & \pm & 0.184 & 8,940 & $\mathrm{~b}$ & \pm & 0.014 & 5.405 & $g$ & \pm & 0.007 \\
\hline 120 & 8.545 & $\mathrm{~cd}$ & \pm & 0.544 & 8,900 & $\mathrm{bc}$ & \pm & 0.028 & 5.425 & $\mathrm{~g}$ & \pm & 0.049 \\
\hline
\end{tabular}

Notes: Values followed by the same letter are not significantly different at $95 \%$ confidence level based on Least Significant Difference Test, AC $=$ Air conditioned room, temperature 19-20\%, relative humidity 50-60\%; Ambient room= temperature $28-31 \%$, relative humidity $70-80 \%$; Refrigator $=$ temperature $0-5 \%$, relative humidity $40-50 \%$ 
Table 2. Germination percentage of jelutung seed based on interaction of drying time and storage room

\begin{tabular}{|c|c|c|c|c|c|c|c|c|c|c|c|c|}
\hline \multirow{4}{*}{$\begin{array}{c}\begin{array}{c}\text { Drying } \\
\text { Time } \\
\text { (Hour) }\end{array} \\
0\end{array}$} & \multicolumn{12}{|c|}{ Room Storage } \\
\hline & \multicolumn{4}{|c|}{$\mathrm{AC}$} & \multicolumn{4}{|c|}{ Ambient Room } & \multicolumn{4}{|c|}{ Refrigerator } \\
\hline & \multicolumn{2}{|c|}{ Average } & \multirow{2}{*}{$\begin{array}{l} \pm \\
\pm\end{array}$} & \multirow{2}{*}{$\begin{array}{c}\begin{array}{c}\text { Standard } \\
\text { Deviation }\end{array} \\
1.155\end{array}$} & \multicolumn{2}{|c|}{ Average } & \multirow{2}{*}{$\begin{array}{l} \pm \\
\pm\end{array}$} & \multirow{2}{*}{$\begin{array}{c}\begin{array}{c}\text { Standard } \\
\text { Deviation }\end{array} \\
2.000\end{array}$} & \multicolumn{2}{|c|}{ Average } & \multirow{2}{*}{$\begin{array}{l} \pm \\
\pm\end{array}$} & \multirow{2}{*}{$\begin{array}{c}\begin{array}{c}\text { Standard } \\
\text { Deviation }\end{array} \\
2.000\end{array}$} \\
\hline & 84.333 & $\mathrm{a}$ & & & 80.000 & $\mathrm{~b}$ & & & 83.000 & $a b$ & & \\
\hline 24 & 75.333 & $\mathrm{c}$ & \pm & 2.517 & 70.333 & de & \pm & 2.517 & 66.333 & ghi & \pm & 4.933 \\
\hline 48 & 72.000 & $\mathrm{~d}$ & \pm & 1.000 & 67.000 & fgh & \pm & 1.000 & 70.000 & def & \pm & 1.000 \\
\hline 72 & 69.333 & defg & \pm & 2.082 & 64.333 & hij & \pm & 2.082 & 67.333 & efgh & \pm & 2.082 \\
\hline 96 & 67.333 & efgh & \pm & 2.082 & 63.000 & $\mathrm{kj}$ & \pm & 1.000 & 66.000 & hij & \pm & 1.000 \\
\hline 120 & 65.333 & hij & \pm & 0.577 & 60.333 & $\mathrm{k}$ & \pm & 0.577 & 63.333 & $\mathrm{ijk}$ & \pm & 0.577 \\
\hline
\end{tabular}

Notes: Values followed by the same letter are not significantly different at 95\% confidence level based on Least Significant Difference Test, $A C=$ Air conditioned room, temperature 19-20\%, relative bumidity 50-60\%; Ambient room $=$ temperature $2831 \%$, relative bumidity $70-80 \%$; Refrigator=temperature 0-5\%, relative bumidity 40-50\%

Table 3. Content of fat, carbohydrate, and protein of jelutung seed treated by interaction of drying time and storage room

\begin{tabular}{|c|c|c|c|c|c|c|c|c|c|}
\hline \multirow{3}{*}{$\begin{array}{c}\text { Drying } \\
\text { Time } \\
\text { (Hours) }\end{array}$} & \multicolumn{9}{|c|}{ Rooms Storage } \\
\hline & \multicolumn{3}{|c|}{$\mathrm{AC}$} & \multicolumn{3}{|c|}{ Ambient room } & \multicolumn{3}{|c|}{ Refrigerator } \\
\hline & $\begin{array}{l}\text { Fat } \\
(\%)\end{array}$ & $\begin{array}{c}\text { Carbohydrate } \\
(\%)\end{array}$ & $\begin{array}{c}\text { Protein } \\
(\%)\end{array}$ & $\begin{array}{l}\text { Fat } \\
(\%)\end{array}$ & $\begin{array}{c}\text { Carbohydrate } \\
(\%)\end{array}$ & $\begin{array}{c}\text { Protein } \\
(\%)\end{array}$ & $\begin{array}{l}\text { Fat } \\
(\%)\end{array}$ & $\begin{array}{c}\text { Carbobydrate } \\
(\%)\end{array}$ & $\begin{array}{c}\text { Protein } \\
(\%)\end{array}$ \\
\hline 0 & $24.8 \mathrm{~g}$ & $13.1 \mathrm{a}$ & $19.5 \mathrm{bc}$ & $18.6 j$ & $9.6 \mathrm{~g}$ & $19.9 \mathrm{bc}$ & $15.3 \mathrm{k}$ & $12.7 \mathrm{ab}$ & $18.7 \mathrm{c}$ \\
\hline 24 & $26.2 \mathrm{ef}$ & $11.1 \mathrm{c}$ & $19.9 \mathrm{bc}$ & $21.3 \mathrm{i}$ & $9.2 \mathrm{gh}$ & $19.9 \mathrm{bc}$ & $25.7 \mathrm{f}$ & $12.0 \mathrm{~b}$ & $19.4 \mathrm{bc}$ \\
\hline 48 & $29.2 \mathrm{c}$ & $10.9 \mathrm{c}$ & $20.2 \mathrm{~b}$ & $21.4 \mathrm{i}$ & $8.3 \mathrm{~h}$ & $19.9 \mathrm{bc}$ & $\begin{array}{c}25.9 \\
\text { ef }\end{array}$ & $10.9 \mathrm{c}$ & $19.5 \mathrm{bc}$ \\
\hline 72 & $\begin{array}{c}29.6 \\
\text { bc }\end{array}$ & $10.8 \mathrm{~cd}$ & $20.2 \mathrm{~b}$ & $23.3 \mathrm{~h}$ & $7.2 \mathrm{i}$ & $20.4 \mathrm{a}$ & 26.6de & $10.6 \mathrm{cdef}$ & $19.6 \mathrm{bc}$ \\
\hline 96 & $\begin{array}{c}30.3 \\
\mathrm{ab}\end{array}$ & $10.8 \mathrm{cde}$ & $20.3 \mathrm{a}$ & $24.3 \mathrm{~g}$ & $7.4 \mathrm{i}$ & $20.4 \mathrm{a}$ & 26.8de & $9.9 \mathrm{efg}$ & $20.1 \mathrm{~b}$ \\
\hline 120 & $30.8 \mathrm{a}$ & $9.9 \mathrm{defg}$ & $20.4 \mathrm{a}$ & $24.7 \mathrm{~g}$ & $4.0 \mathrm{j}$ & $20.5 \mathrm{a}$ & $27.4 \mathrm{~d}$ & $9.9 \mathrm{fg}$ & $20.1 \mathrm{~b}$ \\
\hline
\end{tabular}

Notes: Values followed by the same letter are not significantly different at $95 \%$ confidence level based on Least Significant Difference Test, AC = Air conditioned room, temperature 19-20\%, relative humidity 50-60\%; Ambient room= temperature $28-31 \%$, relative humidity $70-80 \%$; Refrigator=temperature $0-5 \%$, relative humidity $40-50 \%$

reduced the level of carbohydrates. Sudjindro (1994) reported that the seeds which contain high fat, tends to be more easily deteriorated and could decrease the germination percentage.

\section{B. Testing II: Effect of Seed Drying Time and Storage Room on Seed Viability and Nutritional Content}

The analysis of variance shows that interaction of drying time and rooms for storage significantly affected the moisture content ( F calculation 6.84), germination percentage (F calculation 2.22), fat content ( $F$ calculation 122.41), carbohydrate content ( $F$ calculation 28.52), and protein content ( $F$ calculation 3.82). Least Significant Difference test has been applied to learn more about treatments that pose a real difference (see Table 1, Table 2 and Table 3).

Based on the results, it is indicated that time of seed drying and type of storage changed the viability and nutritional content of jelutung seed. Moisture content and germination percentage decreased along with drying time and storage. 
Jelutung seeds that were stored in air conditioned room had better viability compared to ambient room and refrigerator. High temperature and high humidity in tropical regions causing rapid reduction of seeds during storage. The main importance of recalcitrant seeds in storage is to maintain viability over time. Some of the factors that affect seed viability during storage are temperature, moisture content, relative humidity and oxygen. Relative humidity directly influences the moisture content of the seeds, while temperature may increase the rate of biochemical reactions. The storability of seeds in storage is influenced by four factors: genetic (characteristics or seed varieties), viability of the seeds before storage, temperature and relative humidity of room storage and moisture content of the seeds (Harnowo, 2006). Changes of temperature and relative humidity of room storage during storage cause changes in respiration rate of the seeds. Respiration rate continues to increase when the ambient temperature rises. The current speed is inhibited because of things like the inactivation of enzymes, nutrients or oxygen reserves have been consumed or because carbon dioxide accumulated, reaching a level that inhibits the seeds (Sudjindro, 1994). The best way to maintain the viability of recalcitrant seeds is to keep it at low temperatures where most recalcitrant seeds maintain moisture and reduce contamination with fungi (Berjak \& Pammenter, 2008).

After storage, content of fat and protein of jelutung seed increased, while content of carbohydrates decreased. The decline of biochemical seed content indicated by change in enzyme activity, changes in respiration rate, changes in food reserves, changes in the membrane, chromosome damage and accumulation of toxins. The fatty acids can result in damage to the cell membrane (Tatipata, 2008). Increasing fat and protein content in the seed was possibly due to seed retention mechanism against moisture content reduction.

The nutritional content changes during storage of sandalwood seed showed an increase in carbohydrate, protein and electric conductivity (EC) and decreasing fat content (Syamsuwida \& Aminah, 2007). The proportion of fatty acids in the membrane phospholipids is higher for recalcitrant seeds compared to orthodox seed. In some cases it was found that fat content increased because of mold during storage in humid conditions such as occurred to jatropha curcas seed (Worang, Dharmaputra, Syarief \& Miftahudin, 2008).

According to Sudjindro (1994) the seeds that have high fat content will easily be damaged during storage. The high content of fatty acid is also an indication of high respiration process which causes loss of energy for seed germination. During storage, the seeds high in fat are more perishable than seeds containing starch or protein. The decline in water levels and an increase in free fatty acids cause a decrease in viability and vigor.

During seed storage, protein content of jelutung seed also tends to increase along with the decrease of water content and germination. The anticipated increase in the protein content of seeds is a defense mechanism to decrease the moisture content and storage time. It also indicates the defense of seeds in optimal conditions. In addition, the synthesis of specific proteins is needed to maintain dormancy of the embryo (Gifford, 1993). Carbohydrate content of jelutung decreased in the seeds during storage. The presence of carbohydrates in the seed component consisting of sugar (sucrose) as a substrate forming carbohydrates resulted in resistance to drying as well as protein. The decrease indicates a decrease in carbohydrate content meaning decreasing defense of seed viability. This was shown by the jelutung seed germination during storage.

\section{CONCLUSION}

During the seed drying and storage, seed deterioration occurs in viability and nutritional content of jelutung seed. Drying time and type of room storage significantly affected the seed moisture content, germination, and 
nutritional contents (fat, carbohydrate, protein) of jelutung seeds. The longer drying time and storage decreased the moisture content and germination, increased content of fat and protein, but reduced carbohydrates content of the jelutung seed. Jelutung seed that was stored in air conditioned room (temperature $18-20^{\circ} \mathrm{C}$, RH $50-60 \%$ ) had better viability than in the ambient room (temperature $28-31^{\circ} \mathrm{C}, \mathrm{RH} 70$ $80 \%$ ) and refrigerator (temperature $0-5^{\circ} \mathrm{C}, \mathrm{RH}$ $40-50 \%$ ).

\section{ACKNOWLEDGEMENT}

This research was supported by the Forest Tree Seed Technology Research and Development Institute, Ciheuleut, Bogor. Appreciation is extended to Dina Agustina and Abay for helping in conducting this research in the laboratory.

\section{REFERENCES}

Bastoni. (2014). Budidaya jelutung rawa (Dyera lowii Hook. F). Palembang: Balai Penelitian Kehutanan. 20 p.

Bonner, F.T., Karrfalt, R.P., \& Nisley, R.G. (2008). The woody plant seed manual. Washington DC: USDA Forest Service. 1224 p.

Danu \& Wijaya, E. (2012). Daya simpan benih jelutung rawa (Dyera polyphylla Miq.). Paper presented in Seminar Nasional Agroforestri III : 163 - 167. Balai Penelitian Teknologi Agroforestry dan Fakultas Kehutanan (IMHERE), Universitas Gadjah Mada. Yogyakarta.

Berjak P. \& Pammenter, N.W. (2008). From Avicennia to rizania: seed recalcitrance in perspective. Annals Botany, London 101(2), 213-228.

Endress, M.E., Schumann, S.L., \& Meve, U. (2014). An updated classification for Apocynaceae. Phytotaxa, 159(3), 175 - 194.

Gifford, D.J. (1993). Loblolly pine seed dormancy: The relationship between protein, synthesis in the embryo and mega gametophyte and the loss of seed dormancy, In Edward DGW (ed). Dormancy and Barriers to Germination. Proceeding International Symposium Of IUFRO Proj. Group
P2.04.00 (Seed Problems).

Gunawan, H., Mudiyarso, D., Mizuno, K., Kozan, O., Sofiyanti, N., Indriyani, D., Septiani, D., \& Lestari, I. (2016). Taksiran akumulasi biomassa atas permukaan pada eksprimen lahan gambut bekas terbakar, area transisi cagar biosfer Giam Siak Kecil-Bukit Batu, Riau, Sumatera, Indonesia. Jurnal Rian Biologia, 1(2), 8-16.

Harnowo, D. (2006). Teknologi penanganan benih tanaman pangan guna menghasilkan benih bermutu tinggi. Paper presented at Pelatihan Penangkar Benih Tanaman Pangan se NTB, dilaksanakan oleh Dinas Pertanian Propinsi NTB, 12-15 September 2006, 19.

Kartiko, H.D.P \& Danu. (2016). Jelutung (Dyera spp.). Atlas benih tanaman hutan Indonesia Jilid 1. Special publication. Balai Penelitian dan Pengembangan Teknologi Perbenihan Tanaman Hutan, Bogor. 25 - 31pp.

Perdana, A., Sofyuddin, M., Harun, M. \& Widayati, A. (2016). Understanding jelutung (Dyera polyphylla) value chains for the promotion in peatland restoration and sustainable peatland management in Indonesia. Brief, 72. Bogor, Indonesia: World Agroforestry Centre (ICRAF) Southeast Asia Regional Program.

Pramono, A.A. (2012). Pengadaan benih jelutung (Dyera sp.) untuk revegetasi lahan bekas tambang di pulau Bangka. Prosiding seminar hasil-hasilpenelitian "Teknologiperbenihanjenis-jenis potensial untuk rehabilitasi lahan bekas tambang di Provinsi Bangka Belitung”: 123 - 130. Balai Penelitian Teknologi Perbenihan Tanaman Hutan bekerjasama dengan Dinas Kehutanan provinsi Kepulauan Bangka Belitung.

Syamsuwida, D.,\& Aminah, A. (2007). Perubahan kandungan lemak, protein, pati dan daya hantar listrik pada benih gaharu (Aquillaria malaccensis). Jurnal Manajemen Hutan Tropika. Volume XIII, 2, 125-130.

Sudjindro.(1994). Indikasi kemunduran viabilitas oleh dampak guncangan pada benib kenaf (Hibiscus cannabinus L.).[Desertation]. Bogor Agricultural University, Bogor.

Tata. H.L., Noordwijk, M.V., Jasnari \& Widayati, A. (2015a). Domestication of Dyera polyphylla (Miq.) Steenis in peatland agroforestry systems in Jambi, Indonesia. Agroforestry Systems 90, 617-630. 
Tata, H.L., Bastoni, Sofiyuddin, M., Mulyautami, E., Perdana, A \& Janudianto. (2015b). Jelutung rawa: teknik budidaya dan prospek ekonominya. World Agroforestry Centre (ICRAF) bekerjasama dengan Puslitbang Konservasi dan Rehabilitasi, dan Balai Penelitian Kehutanan Palembang. Bogor.

Tatipata, A. (2008). Pengaruh kadar air awal, kemasan dan lama simpan terhadap protein membran dalam mitokondria benih kedelai. Buletin Agronomi, 36(1), 8-16.

Waluyo, T.K., Wahyudi, I. \& Santosa, G. (2012). Pengaruh metode dan arah sadap terhadap produksi getah jelutung Hutan Tanaman Industri. Jurnal Penelitian Hasil Hutan, 30(4), Desember $301-313$.

Widajati, E., Murniati, E., Palupi, E.R., Kartika, T., Suhartanto, M.R., \& Qadir, A. (2012). Dasar ilmu dan teknologi benih. Bogor: IPB Press.
Worang, R.L., Dharmaputra, O.S., Syarief, R., \& Miftahudin. (2008). The quality of physic nut (Jatropha curcas L.) seeds packed in plastic material during storage. Biotropica 15(1), 25-36. Yuniarti, N., Syamsuwida, D., \& Aminah, A. (2008a). Dampak pengeringan terhadap perubahan fisiologi dan biokimia benih mimba(Azadiracbta indica A.Juss). Buletin Puslitbang Perbutani,11(1), 728-735.

Yuniarti, N., Syamsuwida, D., \& Aminah, A. (2008b). Perubahan kandungan biokimia dan fisiologi benih mimba (Aradirachta indica A.Juss) selama penyimpanan. Jurnal Penelitian Hutan Tanaman, 5(2), 259-267. 